\title{
Multipotent Mesenchymal Stromal Cells for Autoimmune Diseases
}

\author{
Alan Tyndall \\ Department of Rheumatology, University of Basel, Felix Platter Spital, Basel, Switzerland
}

\section{Key Words}

Mesenchymal - Stromal · Stem cell · MSC .

Autoimmune disease

\section{Summary}

Multipotent mesenchymal stromal cells (MSC) are under consideration for the treatment of autoimmune disease (AD) based on their in vitro antiproliferative properties, efficacy in animal models, apparent low acute toxicity, and the early positive anecdotal outcomes in human acute graft versus host disease. Phase I/II clinical trials are under way in multiple sclerosis and Crohn's disease, and are being planned in systemic lupus erythematosus, systemic sclerosis, systemic vasculitis, and other AD. Open issues include: patient selection, disease stage and activity, MSC source and expansion, and long-term safety. Multidisciplinary groups including EULAR are collaborating to ensure maximal use of available resources to establish the place, if any, of MSC in the treatment of AD.

\section{Introduction}

Multipotent mesenchymal stromal cells (MSC) are also referred to as mesenchymal stem cells, though their true 'stemness', i.e. on division one daughter cell remains stem and the other is able to replenish a whole tissue compartment, has yet to be demonstrated [1]. MSC are capable of differentiating in vitro and in vivo into different MSC lineages, including adi-

\section{Schlüsselwörter}

Mesenchymal · Stromal · Stammzelle · MSC .

Autoimmunkrankheit

\section{Zusammenfassung}

Aufgrund ihrer antiproliferativen Eigenschaften in vitro, ihrer Effektivität in Tiermodellen, ihrer scheinbar geringen akuten Toxizität sowie aufgrund einzelner Fallberichte positiver Outcomes bei akuter Graft-versus-HostKrankheit beim Menschen wird der Einsatz von multipotenten mesenchymalen Stromazellen (MSC) für die Behandlung von Autoimmunkrankheiten diskutiert. Für multiple Sklerose und Morbus Crohn werden derzeit klinische Phase-I/II-Studien durchgeführt, für systemischen Lupus erythematosus, systemische Sklerose und systemische Vaskulitis sowie andere Autimmunkrankheiten sind sie in der Planung. Folgende Fragen sind offen: Patientenselektion, Krankheitsstadium und -aktivität, MSCQuelle und -Expansion sowie Sicherheit im Langzeitverlauf. Multidisziplinäre Gruppen, einschließlich EULAR, arbeiten zusammen, um bei der Etablierung der Rolle der MSC - wenn sie überhaupt eine spielen - in der Behandlung von Autoimmunkrankheiten die bestmögliche Verwendung vorhandener Ressourcen zu gewährleisten.

pose, bone, cartilage, muscle, and myelosupportive stroma [2-5]. MSC may be isolated from bone marrow, skeletal muscle, adipose tissue, synovial membranes, and other connective tissues of human adults [6-9] as well as cord blood [10] and placental products [11], and are defined by using a combination of phenotypic markers and functional properties. Controversy still exists over the in vivo phenotype of MSC: however, ex vivo-expanded MSC do not express the hematopoietic

\begin{tabular}{ll}
\hline KARGER & $\oplus$ 2008 S. Karger GmbH, Freiburg \\
Fax +49 7614520714 & Accessible online at: \\
$\begin{array}{l}\text { E-mail Information@Karger.de } \\
\text { www.karger.com }\end{array}$ & www.karger.com/tmh
\end{tabular}

Prof. Dr. Alan Tyndall

Department of Rheumatology , University of Basel, Felix Platter Spital Burgfelderstrasse 101, 4012, Basel, Switzerland

Tel.+ 4161326 40-03, Fax -10

E-mail alan.tyndall@fps-basel.ch 
markers CD14, CD34, CD45, and MHC class II. In addition to their multipotentiality, they can be identified as cells that stain positive for CD73, CD90, and CD105 by flow cytometry [12]. In vitro, MSC have vast proliferative potential, can clonally regenerate, and can give rise to differentiated progeny. They also exhibit anti-proliferative and anti-inflammatory properties in vitro and in vivo, making them candidates for treatment of acute inflammatory autoimmune disease (AD) [13]. Regardless of whether or not MSC are true stem cells, clinical benefit from MSC may not require sustained engraftment of large numbers of cells or differentiation into specific tissues. It is possible that a therapeutic benefit can be obtained by local paracrine production of growth factors and a provision of temporary anti-proliferative and immunomodulatory properties. Until recently, it was assumed that MSC enjoyed immune privilege in allogeneic settings [14], neither exerting nor being subject to immunological reaction, but recent data suggest, that in a non-immunosuppressed host, allogeneic MSC will be eliminated [15], especially if gene transfected [16]. In vitro results indicate that MSC possess immunosuppressive properties. Rodent, baboon, and human MSC suppress T and B cell lymphocyte proliferation in mixed lymphocyte cultures or induced by mitogens and antibodies in a dose-dependent fashion [17-24]. The suppression is MHC-independent, and in human cell cultures, the magnitude of suppression is not reduced when the MSC are separated from the lymphocytes in transwells, indicating that cell-cell contact is not required [17, 19, 25]. However, not all experiments have shown anti-proliferative effects. Traggiai et al. [26] studied the influence of bone marrow mesenchymal stem cells on highly purified B cells from healthy donors and children with systemic lupus erythematosus (SLE), and found that they promoted proliferation and differentiation into immunoglobulin-secreting cells of both transitional and naive B cells stimulated with an agonist of Toll-like receptor 9 , in the absence of $\mathrm{B}$ cell receptor triggering. They also strongly enhanced proliferation and differentiation into plasma cells of memory B cell populations. A similar effect was observed in response to polyclonal stimulation of B cells isolated from pediatric patients with SLE.

\section{Mechanism of Immunosuppression and Antiproliferation}

The mechanism(s) underlying the immunosuppressive effect remain to be fully clarified with sometimes conflicting data probably reflecting the variable definitions and experimental conditions. Initially, the fact that MSC when exposed to medium levels of interferon gamma (IFN- $\gamma$ ) express class II antigen but never co-stimulation molecules, suggested that they may induce anergy or apoptosis in cell-cell contact conditions. Unlike professional antigen-presenting cells (APC), MSC have a bimodal response to IFN- $\gamma$ in that low levels stimulate and high levels suppress HLA class II expression [27]. However, apart from one publication involving proliferating lympho- cytes [28], induction of apoptosis has not been shown - in fact arrest of apoptosis may be a major mechanism for MSC imparting a survival signal to other cells such as neutrophils in the bone marrow niche [29]. Transwell experiments have demonstrated putative paracrine soluble factors including hepatocyte growth factor (HGF) and transforming growth factor- $\beta 1$ (TGF- $\beta 1$ ) [19], prostaglandin $\mathrm{E}_{2}$ accounting for reduced lymphocyte proliferation [30], indoleamine 2,3-dioxygenase [31], inducible NO synthetase resulting in Stat 5 inhibition in lymphocytes [32], soluble HLA-G [33], and soluble interleukin 1 receptor [34]. Clearly a major anti-proliferative mechanism in lymphocytes is arrest of the cell cycle in G0/G1 [24].

\section{Fate of Transplanted Mesenchymal Stromal Cells in vivo}

There are scarce data. In animals, radio labeling experiments in rats show localization after intra-arterial and intravenous infusion mostly in lungs and secondarily in liver and other organs [35]. More detailed studies in 3 baboons ( 2 using autologous and 1 allogeneic MSC) and using the green fluorescent protein retroviral construct, showed that gastrointestinal tissues harbored high concentrations of transgene per microgram of DNA. Additional tissues including kidney, lung, liver, thymus, and skin were also found to contain relatively high amounts of DNA equivalents. Estimated levels of engraftment in these tissues ranged from 0.1 to $2.7 \%$, similar in the autologous and allogeneic experiments.

Active homing of MSC to bone marrow occurs largely due to the stromal derived factor-1 (SDF-1) interacting with CXCR4 on the MSC surface [36], and similar mechanisms are operational in ischemic tissue [37]. A new initiative is to modify surface structures on MSC in order to increase their penetration and integration into specific target tissues. It has been shown that recruitment of cells to bone occurs within specialized marrow vessels that constitutively express vascular E-selectin, a lectin that recognizes sialofucosylated determinants on its various ligands. Sackstein et al. [38] showed that human MSC do not express E-selectin ligands, but express a CD44 glycoform bearing alpha-2,3-sialyl modifications. They converted the native CD44 glycoform on MSC into hematopoietic cell E-selectin/L-selectin ligand (HCELL) using an alpha-1,3-fucosyltransferase preparation and enzymatic conditions specifically designed for treating live cells, which conferred potent E-selectin binding without effects on cell viability or multipotency. Real-time intravital microscopy in immunocompromised (NOD/SCID) mice showed that intravenously infused HCELL(+) MSC infiltrated marrow within hours of infusion, with ensuing rare foci of endosteally localized cells and human osteoid generation. If active homing of MSC to inflamed and ischemic tissue were the case in humans, this would increase the feasibility of cellular therapy for $\mathrm{AD}$, since independent of the putative soluble factor(s) produced by them, they would be delivered directly into the target tissue, reducing the need 
for using either large numbers of MSC or high concentrations of biological agents systemically.

MSC homing to tumors is of concern as shown by human MSC localization to a murine xenogenic breast cancer SCID mouse model via monocyte chemotactic protein-1 (MCP-1) [39] which while being a potential therapeutic delivery system for cancer therapy, may pose long-term safety issues in AD treatment. MSC concentrate in radiation damaged and ischemic tissue [40]. This may be an important advantage when treating some acute inflammatory AD with accompanying critical ischemia such as vasculitis or systemic sclerosis (SSc). In humans receiving sex mismatched allogeneic MSC, sex chromosomal analysis of MSC cells have shown to be in the gastrointestinal tract and bone marrow for many months, though extensive data are lacking.

\section{Animal Models of Tissue Protection}

It may be impossible, in fact meaningless, to separate the antiinflammatory, immunomodulatory, and tissue protective 'trophic' effects of MSC [41]. An immunosuppressive effect of MSC in vivo was first suggested in a baboon model where infusion of ex vivo-expanded donor or third-party MSC delayed the time to rejection of histoincompatible skin grafts [22]. MSC also downregulate bleomycin-induced lung inflammation and fibrosis in murine models if given early (but not late) after the induction [42]. A similar effect was seen in a murine hepatic fibrosis model (carbon tetrachloride-induced) using a MSC line bearing the fetal liver kinase-1 (FLK1) marker [43]. More recently, fulminant hepatic failure in a rat model was abrogated by both MSC and MSC-conditioned medium, suggesting a leukocyte diversion mechanism by paracrine substances such as chemokines [44]. Tissue protective effects were also seen in a rat kidney model of ischemia/reperfusion injury in which syngeneic MSC but not fibroblasts were used [45]. Recently, the same group showed a vasculotropic effect of infused MSC in the kidney [46], which may be relevant to diseases such as SSc.

\section{Animal Models of Autoimmunity}

In the two experimental autoimmune encephalomyelitis (EAE) murine models, both clinical and histological improvement occurred. The responses were dependant on time of MSC treatment, the earlier the better, and were reversed with IL-2 treatment, indicating that anergy rather than apoptosis had occurred $[47,48]$. In one model, the MSC were located in the secondary lymph organs but not the central nervous system, despite a positive clinical outcome. This is reminiscent of the induction of regulatory $\mathrm{T}$ cells (Treg) by antigen vaccination [49]. However, in a murine model of arthritis, collagen-induced arthritis (CIA) was not improved by the addition of
MSC, and the in vitro immunosuppressive effects were reversed by the addition of TNF $\alpha$. MSC were not found in the joints [50]. A second murine arthritis model showed however a positive clinical outcome [51].

Recently, a murine model of streptozocin-induced diabetes mellitus was reported to improve clinically following transplantation with a combination of bone marrow-derived cells and syngeneic and allogeneic MSC following sublethal irradiation [52]. The proposed mechanism was regeneration of recipient-derived islet cells plus immunosuppression of autoreacting T cells. Neither cell product alone was effective.

\section{Mesenchymal Stromal Cells and Human Experience}

Ex vivo-expanded allogeneic MSC have been infused in several phase I studies [53-57]. No adverse events during or after MSC infusion have been observed, and no ectopic tissue formation has been noted. After infusion, MSC remain in the circulation for no more than an hour [56]. Although durable stromal cell chimerism has been difficult to establish, low levels of engrafted MSC have been detected in several tissues $[54,57,58]$.

It is possible that sufficient therapeutic benefit is obtained by local paracrine production of growth factors and the provision of temporary immunosuppression by MSC infusion. Infusion of haploidentical MSC to a patient with steroid-resistant severe acute graft versus host disease (GvHD) of the gut and liver promptly improved liver values and intestinal function [59]. Upon discontinuation of cyclosporine, the patient's acute GvHD recurred but was still responsive to a second MSC infusion. Lymphocytes from the patient, when investigated on multiple occasions after MSC infusion, continued to proliferate against lymphocytes derived from the haploidentical MSC donor in co-culture experiments. This suggests an immunosuppressive effect of MSC in vivo, rather than a development of tolerance. The European Group for Blood and Marrow Transplantation (EBMT) is currently running protocols for prevention and treatment of acute GvHD through the Developmental Committee, and interim results of the treatment trial have recently been published [60]. Thirty out of 55 steroid-resistant acute GvHD patients had a complete response with no immediate toxicity. Median dose of allogeneic MSC was $1.4 \times 10^{6} / \mathrm{kg}$ body weight given up to 5 times. Four patients had a recurrence or de novo malignancy, and the complete responders had a reduced transplant-related mortality at 12 months (37 vs. $72 \%$ ) and higher overall 2-year survival (52 vs. 16\%).

\section{Mesenchymal Stromal Cells from Human Autoimmune Disease}

Autologous bone marrow-derived MSC have been shown to be potently anti-proliferative to stimulated $\mathrm{T}$ cells from nor- 
Table 1. Clinical trials using MSC for autoimmune diseases in the US National Institutes of Health (NIH) public web site

\begin{tabular}{|c|c|c|c|c|}
\hline Study title & Disease indication & Center & Interventions & Phase \\
\hline $\begin{array}{l}\text { Prochymal }^{\mathrm{TM}} \text { Adult Human } \\
\text { Mesenchymal Stem Cells for } \\
\text { Treatment of Moderate-to- } \\
\text { Severe Crohn's Disease }\end{array}$ & Crohn's disease & $\begin{array}{l}\text { Osiris } \\
\text { Therapeutics, } \\
\text { USA } \\
\text { (manufacturer) }\end{array}$ & $\begin{array}{l}\text { drug: Prochymal; adult } \\
\text { human mesenchymal } \\
\text { stem cells; drug: adult } \\
\text { human MSC }\end{array}$ & $\begin{array}{l}\text { phase II } \\
\text { active, not recruiting }\end{array}$ \\
\hline $\begin{array}{l}\text { Extended Evaluation of } \\
\text { Prochymal } \\
\text { Stem Adult Human } \\
\text { Resistant for Treatment- } \\
\text { Crohn's Disease }\end{array}$ & Crohn's disease & $\begin{array}{l}\text { Osiris } \\
\text { Therapeutics, } \\
\text { USA }\end{array}$ & $\begin{array}{l}\text { drug: adult human } \\
\text { mesenchymal stem cells; } \\
\text { drug: adult human } \\
\text { mesenchymal stem cells }\end{array}$ & $\begin{array}{l}\text { phase III } \\
\text { recruiting }\end{array}$ \\
\hline $\begin{array}{l}\text { Prochymal }^{\mathrm{TM}} \text { to Treat Crohn's } \\
\text { Disease }\end{array}$ & $\begin{array}{l}\text { colitis; Crohn's } \\
\text { disease; } \\
\text { inflammatory } \\
\text { bowel disease }\end{array}$ & $\begin{array}{l}\text { NIH Clinical } \\
\text { Center }(\mathrm{CC}) \text {, } \\
\text { USA }\end{array}$ & $\begin{array}{l}\text { drug: Prochymal; } \\
\text { mesenchymal stem cells; } \\
\text { procedure: colonoscopy; } \\
\text { procedure: infusion }\end{array}$ & $\begin{array}{l}\text { phase III } \\
\text { recruiting }\end{array}$ \\
\hline $\begin{array}{l}\text { Effect of Mesenchymal Stem } \\
\text { Cell Transplantation for } \\
\text { Lupus Nephritis }\end{array}$ & lupus nephritis & $\begin{array}{l}\text { Organ Transplant } \\
\text { Institute, China }\end{array}$ & $\begin{array}{l}\text { biological: mesenchymal } \\
\text { stem cell }\end{array}$ & $\begin{array}{l}\text { phase } \mathrm{I} / \mathrm{II} \\
\text { not yet recruiting }\end{array}$ \\
\hline $\begin{array}{l}\text { Cotransplantation of Islet } \\
\text { and Mesenchymal Stem Cell } \\
\text { in Type } 1 \text { Diabetic Patients }\end{array}$ & $\begin{array}{l}\text { type } 1 \text { diabetes } \\
\text { mellitus }\end{array}$ & $\begin{array}{l}\text { Fuzhou General } \\
\text { Hospital, China }\end{array}$ & $\begin{array}{l}\text { biological: cotransplanta } \\
\text { tion of islet and } \\
\text { mesenchymal stem cells }\end{array}$ & $\begin{array}{l}\text { phase } \mathrm{I} / \mathrm{II} \\
\text { recruiting }\end{array}$ \\
\hline $\begin{array}{l}\text { Mesenchymal Stem Cells } \\
\text { in Multiple Sclerosis } \\
\text { (MSCIMS) }\end{array}$ & multiple sclerosis & $\begin{array}{l}\text { University of } \\
\text { Cambridge, UK }\end{array}$ & $\begin{array}{l}\text { procedure: intravenous } \\
\text { administration of bone } \\
\text { marrow-derived auto- } \\
\text { logous adult MSC }\end{array}$ & $\begin{array}{l}\text { phase } \mathrm{I} / \mathrm{II} \\
\text { not yet recruiting }\end{array}$ \\
\hline $\begin{array}{l}\text { Evaulation of Prochymal }{ }^{\mathrm{TM}} \\
\text { Adult Human Stem Cells } \\
\text { for Treatment Resistant } \\
\text { Moderate to Severe Crohn's } \\
\text { disease }\end{array}$ & Crohn's disease & $\begin{array}{l}\text { Osiris } \\
\text { Therapeutics, } \\
\text { Duke University, } \\
\text { USA }\end{array}$ & $\begin{array}{l}\text { intravenous, two-dose } \\
\text { ( } 4 \text { infusions over } \\
4 \text { weeks) placebo } \\
\text { controlled double blind }\end{array}$ & $\begin{array}{l}\text { phase III } \\
\text { recruiting }\end{array}$ \\
\hline
\end{tabular}

mal subjects and autoimmune patients (rheumatoid arthritis, SSc, Sjoegrens, SLE) [61], and in SSc patients these MSC were normal in respect to proliferation, clonogenicity, and differentiation into bone and fat [62]. However, one group has shown defective differentiation into endothelial precursors in bone marrow-derived MSC from SSc patients [63], which should be considered when choosing autologous or allogeneic MSC sources for SSc treatment. MSC are being tested widely as potential agents for increasing neovascularization in critical ischemia settings, with the attendant risk of increasing tumor growth [64]. In fact, MSC may also play a role in reducing tumor surveillance, as shown in a murine melanoma model [65].

\section{Mesenchymal Stromal Cells for Human Autoimmune Disease}

Currently, few peer-reviewed publications concerning the results of using MSC in human AD are available. A small series of 10 multiple sclerosis (MS) patients from Iran was reported using autologous intrathecal MSC. The conclusion was that it was feasible, the clinical results being mixed. A small study in Crohn's disease has been announced by Osiris Therapeutics Inc., Baltimore, MD, USA [66] - details of the outcome being not yet available.

\section{Ongoing Studies and Future Directions}

There are several running phase I/II and III clinical trials in AD including MS, Crohn's disease, and type I diabetes mellitus. Table 1 shows the AD studies registered in the US National Institutes of Health public information site ( $w w w$. clinicaltrials.gov). A total of 43 trials are registered under MSC trials, 10 being for GvHD, 7 for cardiological indications, 7 for $\mathrm{AD}$, and the rest for various tissue engineering and tissue protection indications. Important is the setting of clear therapeutic targets and harmonization of cell products, especially MSC source and type (autologous or allogeneic), cell expansion conditions, and trial protocols. In addition, long-term safety data collection across disciplines is required, and an inter- 
national interdisciplinary registry of MSC-treated patients has been launched [67].

\section{Conclusion}

There are now data to suggest that the benefit/risk ratio for MSC in human is acceptable, mostly derived from acute GvHD studies. The fact that conditioning of the patient with cytotoxic and other immunosuppressive agents is not necessary prior to MSC infusion, makes such a treatment attractive in a critically ill patient who would be unable to tolerate an autologous hematopoietic stem cell transplant, an alternative strategy for severe AD not responding to conventional therapy.
The choice of patient, i.e. multisystem, inflammatory disease similar to acute GvHD or less active end stage disease, depends on whether the study aim is efficacy or feasibility/safety. Immune privilege of MSC is not guaranteed in an immune competent host, but that may not be important if the MSC home to the target organ and survive long enough to exert a positive therapeutic effect. Clearly, an international and interdisciplinary effort is required, as is being undertaken by the European League Against Rheumatism (EULAR) and EBMT [68].

\section{Conflicts of Interest}

The author has no conflict of interests.

\section{References}

1 Javazon EH, Beggs KJ, Flake AW: Mesenchymal stem cells: paradoxes of passaging. Exp Hematol 2004:32:414-25.

2 Friedenstein AJ, Petrakova KV, Kurolesova AI, Frolova GP: Heterotopic of bone marrow. Analysis of precursor cells for osteogenic and hematopoietic tissues. Transplantation 1968;6:230-47.

3 Haynesworth SE, Goshima J, Goldberg VM, Caplan AI: Characterization of cells with osteogenic potential from human marrow. Bone 1992;13:81-8.

4 Prockop DJ: Marrow stromal cells as stem cells for nonhematopoietic tissues. Science 1997;276:71-4.

5 Pittenger MF, Mackay AM, Beck SC, Jaiswal RK, Douglas R, Mosca JD, et al: Multilineage potential of adult human mesenchymal stem cells. Science 1999;284:143-7.

6 Friedenstein AJ, Deriglasova UF, Kulagina NN, Panasuk AF, Rudakowa SF, Luria EA, et al: Precursors for fibroblasts in different populations of hematopoietic cells as detected by the in vitro colony assay method. Exp Hematol 1974;2:83-92.

7 Nakahara H, Dennis JE, Bruder SP, Haynesworth SE, Lennon DP, Caplan AI: In vitro differentiation of bone and hypertrophic cartilage from periostealderived cells. Exp Cell Res 1991;195:492-503.

8 Sampath TK, Nathanson MA, Reddi AH: In vitro transformation of mesenchymal cells derived from embryonic muscle into cartilage in response to extracellular matrix components of bone. Proc Natl Acad Sci U S A 1984;81:3419-23.

- Jones EA, Kinsey SE, English A, Jones RA, Straszynski L, Meredith DM, et al: Isolation and characterization of bone marrow multipotential mesenchymal progenitor cells. Arthritis Rheum 2002;46:3349-60.

10 Bieback K, Kluter H: Mesenchymal stromal cells from umbilical cord blood. Curr Stem Cell Res Ther 2007;2:310-23.

11 Soncini M, Vertua E, Gibelli L, Zorzi F, Denegri M, Albertini A, et al: Isolation and characterization of mesenchymal cells from human fetal membranes. J Tissue Eng Regen Med 2007;1:296-305.

$\checkmark 12$ Horwitz E, Le Blanc K, Dominici M, Mueller I, Slaper-Cortenbach I, Marini F, et al: Clarification of the nomenclature for MSC: The International Society for Cellular Therapy position statement. Cytotherapy 2005;7:393-5.

13 Tyndall A, LeBlanc K: Stem cells and rheumatology: update on adult stem cell therapy in autoimmune diseases. Arthritis Rheum 2006;55:521-5.
14 Le Blanc K: Immunomodulatory effects of fetal and adult mesenchymal stem cells. Cytotherapy 2003;5:485-9.

15 Nauta AJ, Westerhuis G, Kruisselbrink AB, Lurvink EG, Willemze R, Fibbe WE: Donor-derived mesenchymal stem cells are immunogenic in an allogeneic host and stimulate donor graft rejection in a nonmyeloablative setting. Blood 2006;108: 2114-20.

16 Eliopoulos N, Stagg J, Lejeune L, Pommey S, Galipeau J: Allogeneic marrow stromal cells are immune rejected by MHC class I- and class II-mismatched recipient mice. Blood 2005;106:4057-65.

17 Tse WT, Pendleton JD, Beyer WM, Egalka MC, Guinan EC: Suppression of allogeneic T-cell proliferation by human marrow stromal cells: implications in transplantation. Transplantation 2003;75: 389-97.

18 Le Blanc K, Tammik L, Sundberg B, Haynesworth SE, Ringden O: Mesenchymal stem cells inhibit and stimulate mixed lymphocyte cultures and mitogenic responses independently of the major histocompatibility complex. Scand J Immunol 2003;57:11-20.

19 Di Nicola M, Carlo-Stella C, Magni M, Milanesi M, Longoni PD, Matteucci P, et al: Human bone marrow stromal cells suppress T-lymphocyte proliferation induced by cellular or nonspecific mitogenic stimuli. Blood 2002;99:3838-43.

20 Klyushnenkova E, Mosca JD, Zernetkina V, Majumdar MK, Beggs KJ, Simonetti DW, et al: T cell responses to allogeneic human mesenchymal stem cells: immunogenicity, tolerance, and suppression. J Biomed Sci 2005;12:47-57.

21 Krampera M, Glennie S, Dyson J, Scott D, Laylor $\mathrm{R}$, Simpson E, et al: Bone marrow mesenchymal stem cells inhibit the response of naive and memory antigen-specific $\mathrm{T}$ cells to their cognate peptide. Blood 2003;101:3722-9.

22 Bartholomew A, Sturgeon C, Siatskas M, Ferrer K, McIntosh K, Patil S, et al: Mesenchymal stem cells suppress lymphocyte proliferation in vitro and prolong skin graft survival in vivo. Exp Hematol 2002; 30:42-8.

23 Corcione A, Benvenuto F, Ferretti E, Giunti D, Cappiello V, Cazzanti F, et al: Human mesenchymal stem cells modulate B-cell functions. Blood 2006; 107:367-72.

24 Glennie S, Soeiro I, Dyson PJ, Lam EW, Dazzi F: Bone marrow mesenchymal stem cells induce division arrest anergy of activated T cells. Blood 2005; 105:2821-7.
25 Rasmusson I, Ringden O, Sundberg B, LeBlanc K: Mesenchymal stem cells inhibit the formation of cytotoxic $\mathrm{T}$ lymphocytes, but not activated cytotoxic $\mathrm{T}$ lymphocytes or natural killer cells. Transplantation 2003;76:1208-13.

26 Traggiai E, Volpi S, Schena F, Gattorno M, Ferlito F, Moretta L, et al: Bone marrow-derived mesenchymal stem cells induce both polyclonal expansion and differentiation of B cells isolated from healthy donors and systemic lupus erythematosus patients. Stem Cells 2008;26:562-9.

27 Tang KC, Trzaska KA, Smirnov SV, Kotenko SV, Schwander SK, Ellner JJ, et al: Down-regulation of MHC II in mesenchymal stem cells at high IFNgamma can be partly explained by cytoplasmic retention of CIITA. J Immunol 2008;180:1826-33.

28 Plumas J, Chaperot L, Richard MJ, Molens JP, Bensa JC, Favrot MC: Mesenchymal stem cells induce apoptosis of activated T cells. Leukemia 2005; 19:1597-604.

29 Raffaghello L, Bianchi G, Bertolotto M, Montecucco F, Busca A, Dallegri F, et al: Human mesenchymal stem cells inhibit neutrophil apoptosis: a model for neutrophil preservation in the bone marrow niche. Stem Cells 2008;26:151-62.

30 Aggarwal S, Pittenger MF: Human mesenchymal stem cells modulate allogeneic immune cell responses. Blood 2005;105:1815-22.

31 Meisel R, Zibert A, Laryea M, Gobel U, Daubener W, Dilloo D: Human bone marrow stromal cells inhibit allogeneic T-cell responses by indoleamine 2,3-dioxygenase-mediated tryptophan degradation. Blood 2004;103:4619-21.

32 Sato K, Ozaki K, Oh I, Meguro A, Hatanaka K, Nagai T, et al: Nitric oxide plays a critical role in suppression of T-cell proliferation by mesenchymal stem cells. Blood 2007;109:228-34.

33 Nasef A, Mathieu N, Chapel A, Frick J, Francois S, Mazurier C, et al: Immunosuppressive effects of mesenchymal stem cells: involvement of HLA-G. Transplantation 2007;84:231-7.

34 Ortiz LA, Dutreil M, Fattman C, Pandey AC, Torres G, Go K, et al: Interleukin 1 receptor antagonist mediates the antiinflammatory and antifibrotic effect of mesenchymal stem cells during lung injury. Proc Natl Acad Sci U S A 2007;104:11002-7.

-35 Gao J, Dennis JE, Muzic RF, Lundberg M, Caplan AI: The dynamic in vivo distribution of bone marrow-derived mesenchymal stem cells after infusion. Cells Tissues Organs 2001;169:12-20. 
\36 Wynn RF, Hart CA, Corradi-Perini C, O’Neill L, Evans CA, Wraith JE, et al: A small proportion of mesenchymal stem cells strongly expresses functionally active CXCR4 receptor capable of promoting migration to bone marrow. Blood 2004;104: 2643-5.

37 Fox JM, Chamberlain G, Ashton BA, Middleton J: Recent advances into the understanding of mesenchymal stem cell trafficking. Br J Haematol 2007; 137:491-502.

38 Sackstein R, Merzaban JS, Cain DW, Dagia NM, Spencer JA, Lin CP, et al: Ex vivo glycan engineering of CD44 programs human multipotent mesenchymal stromal cell trafficking to bone. Nat Med 2008;14:181-7.

\$3 Dwyer RM, Potter-Beirne SM, Harrington KA, Lowery AJ, Hennessy E, Murphy JM, et al: Monocyte chemotactic protein-1 secreted by primary breast tumors stimulates migration of mesenchymal stem cells. Clin Cancer Res. 2007;13:5020-7.

40 Mouiseddine M, Francois S, Semont A, Sache A, Allenet B, Mathieu N, et al: Human mesenchymal stem cells home specifically to radiation-injured tissues in a non-obese diabetes/severe combined immunodeficiency mouse model. Br J Radiol 2007;80 (spec no 1):S49-55.

41 Caplan AI, Dennis JE: Mesenchymal stem cells as trophic mediators. J Cell Biochem 2006;98:1076-84.

42 Ortiz LA, Gambelli F, McBride C, Gaupp D, Baddoo M, Kaminski N, et al: Mesenchymal stem cell engraftment in lung is enhanced in response to bleomycin exposure and ameliorates its fibrotic effects. Proc Natl Acad Sci U S A 2003;100:8407-11.

43 Fang B, Shi M, Liao L, Yang S, Liu Y, Zhao RC: Systemic infusion of FLK1(+) mesenchymal stem cells ameliorate carbon tetrachloride-induced liver fibrosis in mice. Transplantation 2004;78:83-8.

44 Parekkadan B, van Poll D, Suganuma K, Carter EA, Berthiaume F, Tilles AW, et al: Mesenchyma stem cell-derived molecules reverse fulminant hepatic failure. PLoS ONE 2007;2:e941.

45 Togel F, Hu Z, Weiss K, Isaac J, Lange C, Westenfelder $\mathrm{C}$, et al: Amelioration of acute renal failure by stem cell therapy - paracrine secretion versus transdifferentiation into resident cells: administered mesenchymal stem cells protect against ischemic acute renal failure through differentiationindependent mechanisms. Am J Physiol Renal Physiol 2005;289:F31-42.

46 Togel F, Weiss K, Yang Y, Hu Z, Zhang P, Westenfelder C: Vasculotropic, paracrine actions of infused mesenchymal stem cells are important to the recovery from acute kidney injury. Am J Physiol Renal Physiol 2007;292:F1626-35.

47 Zhang J, Li Y, Chen J, Cui Y, Lu M, Elias SB, et al: Human bone marrow stromal cell treatment improves neurological functional recovery in EAE mice. Exp Neurol 2005;195:16-26.
48 Zappia E, Casazza S, Pedemonte E, Benvenuto F, Bonanni I, Gerdoni E, et al: Mesenchymal stem cells ameliorate experimental autoimmune encephalomyelitis inducing T-cell anergy. Blood 2005; 106:1755-61

49 Van Eden W, Wick G, Albani S, Cohen I: Stress, heat shock proteins, and autoimmunity: how immune responses to heat shock proteins are to be used for the control of chronic inflammatory diseases. Ann N Y Acad Sci 2007;1113:217-37.

50 Djouad F, Fritz V, Apparailly F, Louis-Plence P, Bony C, Sany J, et al: Reversal of the immunosuppressive properties of mesenchymal stem cells by tumor necrosis factor alpha in collagen-induced arthritis. Arthritis Rheum 2005;52:1595-603.

51 Augello A, Tasso R, Negrini SM, Cancedda R, Pennesi G: Cell therapy using allogeneic bone marrow mesenchymal stem cells prevents tissue damage in collagen-induced arthritis. Arthritis Rheum 2007; 56:1175-86.

52 Urban VS, Kiss J, Kovacs J, Gocza E, Vas V, Monostori E, et al: Mesenchymal stem cells cooperate with bone marrow cells in therapy of diabetes. Stem Cells 2008;26:244-53.

53 Lazarus HM, Haynesworth SE, Gerson SL, Rosenthal NS, Caplan AI: Ex vivo expansion and subsequent infusion of human bone marrow-derived stromal progenitor cells (mesenchymal progenitor cells): implications for therapeutic use. Bone Marrow Transplant 1995;16:557-64.

54 Lazarus HM, Koc ON, Devine SM, Curtin P, Maziarz RT, Holland HK, et al: Cotransplantation of HLA-identical sibling culture-expanded mesenchymal stem cells and hematopoietic stem cells in hematologic malignancy patients. Biol Blood Marrow Transplant 2005;11:389-98.

55 Koc ON, Day J, Nieder M, Gerson SL, Lazarus HM, Krivit W: Allogeneic mesenchymal stem cell infusion for treatment of metachromatic leukodystrophy (MLD) and Hurler syndrome (MPS-IH). Bone Marrow Transplant 2002;30:215-22.

56 Koc ON, Gerson SL, Cooper BW, Dyhouse SM, Haynesworth SE, Caplan AI, et al: Rapid hematopoietic recovery after coinfusion of autologousblood stem cells and culture-expanded marrow mesenchymal stem cells in advanced breast cancer patients receiving high-dose chemotherapy. J Clin Oncol 2000;18:307-16.

57 Horwitz EM, Gordon PL, Koo WK, Marx JC, Neel $\mathrm{MD}, \mathrm{McNall} \mathrm{RY}$, et al: Isolated allogeneic bone marrow-derived mesenchymal cells engraft and stimulate growth in children with osteogenesis imperfecta: implications for cell therapy of bone. Proc Natl Acad Sci U S A 2002;99:8932-7.
58 Fouillard L, Bensidhoum M, Bories D, Bonte H, Lopez M, Moseley AM, et al: Engraftment of allogeneic mesenchymal stem cells in the bone marrow of a patient with severe idiopathic aplastic anemia improves stroma. Leukemia 2003;17:474-6.

59 Le Blanc K, Rasmusson I, Sundberg B, Gotherstrom C, Hassan M, Uzunel M, et al: Treatment of severe acute graft-versus-host disease with third party haploidentical mesenchymal stem cells. Lancet 2004;363:1439-41.

60 Le Blanc K, Frassoni F, Ball L, Locatelli F, Roelofs $\mathrm{H}$, Lewis I, et al: Mesenchymal stem cells for treatment of steroid-resistant, severe, acute graft-versushost disease: a phase II study. Lancet 2008;371: 1579-86.

61 Bocelli-Tyndall C, Bracci L, Spagnoli G, Braccini A Bouchenaki M, Ceredig R, et al: Bone marrow mesenchymal stromal cells (BM-MSCs) from healthy donors and auto-immune disease patients reduce the proliferation of autologous- and allogeneicstimulated lymphocytes in vitro. Rheumatology (Oxford) 2007;46:403-8.

62 Larghero J, Farge D, Braccini A, Lecourt S, Scherberich A, Fois E, et al: Phenotypical and functional characteristics of in vitro expanded bone marrow mesenchymal stem cells from systemic sclerosis patients. Ann Rheum Dis 2008;67:443-9.

63 Cipriani P, Guiducci S, Miniati I, Cinelli M, Urbani S, Marrelli A, et al: Impairment of endothelial cel differentiation from bone marrow-derived mesenchymal stem cells: new insight into the pathogenesis of systemic sclerosis. Arthritis Rheum 2007; 56:1994-2004.

64 Ball SG, Shuttleworth CA, Kielty CM: Mesenchymal stem cells and neovascularization: role of platelet-derived growth factor receptors. J Cell Mol Med 2007;11:1012-30.

65 Djouad F, Plence P, Bony C, Tropel P, Apparailly F, Sany J, et al: Immunosuppressive effect of mesenchymal stem cells favors tumor growth in allogeneic animals. Blood 2003;102:3837-44.

66 Taupin P: OTI-010 Osiris Therapeutics/JCR Pharmaceuticals. Curr Opin Investig Drugs 2006;7: 473-81.

67 Le Blanc K, Fibbe W: A new cell therapy registry coordinated by the European Group for Blood and Marrow Transplantation (EBMT). Bone Marrow Transplant 2008;41:319.

68 Tyndall A, Walker U, Cope A, Dazzi F, De Bari C, Fibbe W, et al: Immunomodulatory properties of mesenchymal stem cells - a review based on an interdisciplinary meeting held at the Kennedy Institute of Rheumatology Division, London, UK, 31 October 2005. Arthritis Res Ther 2007;9:301. 